\title{
Cucurbit Powdery Mildew-resistant Bitter Gourd Breeding Lines Reveal Four Races of Podosphaera xanthii in Asia
}

Narinder P. S. Dhillon ${ }^{2}$, Supannika Sanguansil ${ }^{1}$, and Supornpun Srimat

World Vegetable Center East and Southeast Asia/Oceania, Kasetsart University, Kamphaeng Saen, Nakhon Pathom 73140, Thailand

Roland Schafleitner

Biotechnology, World Vegetable Center, P.O. Box 42, Shanhua, Tainan 74199, Taiwan

B. Manjunath

Rasi Seeds Private Limited, Plot No. 20, KIADB Industrial Area, Kasaba Hobli, Veerapura Post, Bangalore 561203, India

Parag Agarwal

VNR Seeds Private Limited, Corporate Center, Ring Road No. 1, Raipur 492006, India

Qu Xiang

Clover Seed Company Limited, No. 8, Jiang June Shan Road West, Tang Kou Town, Kaiping City, Guang Dong Province, China

Mohammed Abu Taher Masud

Vegetable Division, Horticultural Research Center, Bangladesh Agricultural Research Institute, Joydebpur, Gazipur 1701, Bangladesh

Thaingi Myint

Horticulture Section, Department of Agricultural Research, Yezin, Nay Pyi Taw, Myanmar

Ngo Thi Hanh

Department of Vegetable and Spices, Fruit and Vegetable Research Institute, Trau Quy, Gia Lam, Hanoi, Vietnam

Tran Kim Cuong

Southern Horticultural Research Institute (SOFRI), Long Dinh, Chan Thanh, Tien Giang, Vietnam

Conrado H. Balatero and Venus Salutan-Bautista

East West Seed Company, Inc., Km. 54 Cagayan Valley Road, Sampaloc, San Rafael 3008, Bulacan, Philippines

Michel Pitrat

INRA (French National Institute for Agricultural Research), GAFL (Genetics and Breeding of Fruit and Vegetables), Domaine Saint Maurice, CS 60094, 84143 Montfavet, France

Aleš Lebeda

Department of Botany, Faculty of Science, Palacký University in Olomouc, Šlechtitelì 27, 78371 Olomouc-Holice, Czech Republic

James D. McCreight

U.S. Department of Agriculture, Agricultural Research Service, U.S. Agricultural Research Station, 1636 E. Alisal Street, Salinas, CA 93905

Additional index words. Momordica charantia, Podosphaera xanthii, physiological races, resistance breeding, virulence variation

Abstract. Bitter gourd (Momordica charantia L.) is a commercially and nutritionally important market vegetable in Asia cultivated mainly by smallholder farmers. Cucurbit powdery mildew (CPM) caused by Podosphaera xanthii (Px) is a nearly ubiquitous and serious fungal disease of bitter gourd. Five bitter gourd breeding lines (THMC 113, THMC 143, THMC 153, THMC 167, and THMC 170) were selected at the World Vegetable Center for resistance to a local isolate of $P x$ in Kamphaeng Saen, Thailand. We evaluated the resistance potential of these five inbred lines against local isolates of $P x$ at 12 locations in five Asian countries. Plants were inoculated with the respective local $P x$ isolate 15 and 30 days after transplanting and additional $P x$-infected plants of the inoculated control were interplanted throughout each test. Plants were rated 60 days after transplanting for CPM reaction using a 0 (no evidence of infection) to 5 ( $>75 \%$ infection evident on individual leaves) disease severity scale. THMC 153 and THMC 167 were resistant to the local race of $P x$ in all locations, whereas THMC 143 was observed resistant in all test locations except one in China. THMC 113 was resistant in each location except one in India. THMC 170 was susceptible in three locations in India. The multilocation tests revealed four unique $P x$ races on bitter gourd in different Asian countries and sources of resistance for breeding CPM-resistant bitter gourd cultivars. Six strains of $P x$ isolated from other cucurbits (Cucumis and $C$ ucurbita) and representing five melon CPM races were unable to infect the susceptible $M$. charantia accession THMC 144 and the five resistant breeding lines, indicating pathotype differences between them and an isolate of $M$. charantia origin typed as race 1 on melon. THMC 143 and THMC 167, which originated from India, exhibited good yield potential in trials conducted in Thailand, Myanmar, Vietnam, and Bangladesh. 
Bitter gourd (M. charantia L.) is an important cucurbitaceous market vegetable in Asia, where more than 340,000 ha are devoted to its cultivation annually (McCreight et al., 2013). Its cultivation is gaining popularity in some African countries such as Ghana, Zambia, Congo, and Madagascar for local consumption or for export to Europe and the Middle East to cater the demand of emigrant Asian communities. It is also cultivated to a lesser extent in the southern United States and Australia (Northern Territory, Queensland, New South Wales, and Victoria), where popular Asian hybrid cultivars are cultivated for consumption mainly by ethnic communities from Asia (Morgan and Midmore, 2002).

Bitter gourd fruit is a rich source of betacarotene, vitamin $\mathrm{C}$, folic acid, magnesium, phosphorus, and potassium (Dhillon et al., 2017; Yuwai et al., 1991). The health and pharmacological properties of bitter gourd have been well documented (Tan et al., 2016). Currently, 422 million people worldwide have diabetes (World Health Organization, 2016) and Type 2 diabetes accounts for around 90\% (379 million). Bitter gourd fruit is used in folk medicine to manage Type 2 diabetes (Abascal and Yarnell, 2005; Grover and Yadav, 2004; Lans, 2006).

Cucurbit powdery mildew (CPM) caused by $P x$ is a serious fungal foliar disease of cucurbit production in open fields and greenhouses. Disease outbreak brings reduction in plant growth, premature foliage loss, and reduction in yield and fruit quality (Keinath and DuBose, 2004). CPM on bitter gourd is currently controlled by fungicides, although fungicide resistance has developed in some areas (Lebeda et al., 2010; McGrath, 2006). The pathogen is highly variable in virulence and represented by many pathotypes (Lebeda et al., 2011) and races (Lebeda et al., 2016). The use of disease-resistant varieties is an economical and safe approach for disease management. Accessions resistant to CPM have been identified in melon (Cucumis melo; Dhillon et al., 2012), watermelon

Received for publication 2 Oct. 2017. Accepted for publication 11 Jan. 2018.

Funding for this research was provided by the Federal Ministry for Economic Cooperation and Development, Germany (BMZ), Japan Ministry of Agriculture, Forestry and Fisheries (Japan MAFF), and core donors to the World Vegetable Center: Republic of China (ROC), UK Department for International Development (UK aid), United States Agency for International Development (USAID), Australian Center for International Agricultural Research (ACIAR), Germany, Thailand, Philippines, Korea, and Japan. A. Lebeda was supported by the following grants: MSM 6198959215 (Czech Ministry of Education); QH 71229 (NAZV, National Agency for Agricultural Research of the Czech Republic); Internal Grant Agency of Palacky University in Olomouc (Prf_2017_001). Technical support of Sorawit Limsiriwat is acknowledged.

${ }^{1}$ Current address: Chia Tai Company Limited, Khwang Samphanthawong, Khet Samphanthawong, Bangkok 10100, Thailand.

${ }^{2}$ Corresponding author. E-mail: narinder.dhillon@, worldveg.org.
(Citrullus lanatus; Thomas et al., 2005), cucumber (Cucumis sativus; Block and Reitsma, 2005), squash (Cucurbita pepo; Lebeda and Křístková, 1996), pumpkin (Cucurbita moschata; Wessel-Beaver, 1993), and bottle gourd (Lagenaria siceraria; Kousik et al., 2008). Resistance to CPM is, however, often race-specific and not durable (Lebeda et al., 2008, 2016).

Commercial cultivars of bitter gourd resistant to CPM are not currently available. We developed five inbred lines resistant to CPM after screening 150 accessions of a global collection of bitter gourd in the World Vegetable Center genebank against the local CPM population at Kamphaeng Saen (Thailand). A single resistant plant was identified in each of five segregating populations derived from five genebank accessions that originated from India, Thailand, Taiwan, and Belize. Multiple cycles of inbreeding and selection led to the development of the five CPM-resistant inbred lines. We evaluated four of these inbred lines in 2011 against local isolates of $P x$ in Thailand, Taiwan, and the United States (South Carolina, Florida, California) (Dhillon et al., 2015). We report here the reactions of the five bitter gourd CPM-resistant inbred lines against local isolates of $P x$ at 12 locations in five Asian countries (China, India, Thailand, Vietnam, and Philippines) in 2013 and 2014. In addition, we sought to relate Asian CPMbitter gourd interactions to the more developed body of knowledge of CPM-melon interactions, first by challenging these lines with European and the Mediterranean CPM isolates, and second by challenging a set of melon CPM race differentials with a singlespore strain isolated from a local isolate of $P x$ on bitter gourd from Kamphaeng Saen, Thailand. The latter test also challenged representatives of cucumber, summer squash, and watermelon, cucurbit species on which few CPM races have been identified, with the exception of watermelon where four CPM races have been defined (Davis et al., 2007; Kousik et al., 2011; Mercier et al., 2014; Zhang et al., 2011). Furthermore, we evaluated horticultural fruit characters of the CPM-resistant bitter gourd breeding lines in the field test at Kamphaeng Saen, Thailand in 2014, and assessed the yield potential of two of the lines in Thailand, Myanmar, Vietnam, and Bangladesh in 2016, to assess their horticultural value as sources of CPM resistance.

\section{Materials and Methods}

Germplasm and field test sites. Five bitter gourd CPM-resistant inbred lines and a susceptible bitter gourd check line were evaluated against the respective local $P x$ isolates at 12 locations in five countries in 2013 and 2014 (Table 1). Each field test was planted in a randomized complete block design with three replications of five plants per plot. Entries were planted on raised, 1.6-m wide beds covered with black plastic mulch. Plots were 5-m long on a single bed; each consisted of five transplants spaced 1-m apart. Plants were trellised on the plastic net erected on vertical bamboo poles.

Field test. At each location, a spore suspension was prepared by detaching heavily sporulating leaves of susceptible THMC 144 and washing them with a spray of $100 \mathrm{~mL}$ of water and filtering through a double layer of cheesecloth. The suspension was diluted to a concentration of $4 \times 10^{4}$ conidia $/ \mathrm{mL}$ of water as determined by a hemocytometer. This was freshly prepared as required for each inoculation. Seedlings were inoculated 15 and $30 \mathrm{~d}$ after transplanting, at the threeleaf stage of growth, at each location. The spore suspension was sprayed over the plants until runoff, by using a pressurized sprayer. THMC 144 plants with abundantly sporulating CPM were used as spreader plants, placed between rows as additional sources of powdery mildew inoculum.

Disease severity was rated on leaves of individual plants $30 \mathrm{~d}$ after the second inoculation using a $0-5$ visual rating scale, where $0=$ no symptom; $1=1 \%$ to $10 \%$; $2=11 \%$ to $25 \% ; 3=26 \%$ to $50 \% ; 4=51 \%$ to $75 \%$; and $5=>75 \%$ of leaf surface covered by mycelium. Plant ratings of 0 and 1 were considered resistant. The susceptible check had a mean rating of 5.0 at all test locations. The $0-5$ scale was converted to percentage using midpoints: $0=0 \%, 1=5.5 \%, 2=18 \%, 3=$ $38 \%, 4=63 \%$, and $5=97 \%$ and the data were subjected to analysis of variance (ANOVA) using SAS general linear model (GLM) procedure (SAS Institute, Cary, NC). Mean separation was performed using Fisher's least significant differences (LSD) at $P \leq 0.05$.

Growth chamber tests. There were two growth chamber tests. The first evaluated the five breeding lines against European and Mediterranean CPM isolates, whereas the second evaluated various cucurbits with a single-spore CPM strain from Kamphaeng Saen, Thailand. Five plants, each of the five bitter gourd CPM-resistant inbred lines, and a susceptible check (Table 2) were inoculated at two-leaf stage, similarly as explained previously, with six CPM strains isolated from cucurbits in Europe and the Mediterranean area and typed for race on melon: Sm3 (race 1), S87-7 (race 2F), $00 \mathrm{Sm} 39$ (race 3), 98Sm65 (race 5), and $04 \mathrm{Sm} 2$ and $08 \mathrm{Sm} 9$ (race 3.5 ). A singlespore CPM strain isolated from $M$. charantia grown in an open field in Kamphaeng Saen, Thailand, was inoculated on five plants each of 'Marketer' cucumber, 'Diamant' summer squash, 'Sugar Baby' watermelon, and melon CPM race differentials ['Védrantais', 'PMR 45', 'PMR 5', WMR 29, PI 124112, 90625 (PI 313970), and AR Hale's Best Jumbo]. Plants were raised in a glasshouse until the second leaf stage and then incubated after inoculation in a growth chamber $\left(16 \mathrm{~h}\right.$ day $26^{\circ} \mathrm{C} / 8 \mathrm{~h}$ night $\left.20^{\circ} \mathrm{C}\right)$ at GAFL, INRA, Montfavet, France. Disease severity was rated on leaves of individual plants after $10-14 \mathrm{~d}$ of inoculation, using $0-3$ visual rating scale, where $0=$ no visible 
Table 1. Summary disease ratings and mean disease reactions of six bitter gourd breeding lines and a susceptible control (THMC 144) to cucurbit powdery mildew incited by Podosphaera xanthii in field tests at 12 locations in five countries, and tentative bitter gourd powdery mildew race designations based on the reaction patterns of the breeding lines.

\begin{tabular}{|c|c|c|c|c|c|c|c|c|c|}
\hline \multirow[b]{3}{*}{ Country } & \multirow[b]{3}{*}{ Location } & \multirow{3}{*}{$\begin{array}{l}\text { Transplant } \\
\text { date }\end{array}$} & \multicolumn{6}{|c|}{ Summary disease rating (mean disease reaction $)^{\mathrm{z}}$} & \multirow{3}{*}{$\begin{array}{l}\text { Tentative bitter } \\
\text { gourd powdery } \\
\text { mildew race }\end{array}$} \\
\hline & & & \multirow{2}{*}{$\begin{array}{l}\text { Susceptible } \\
\text { control }\end{array}$} & \multicolumn{5}{|c|}{ Breeding line } & \\
\hline & & & & THMC 113 & THMC 143 & THMC 153 & THMC 167 & THMC 170 & \\
\hline \multirow[t]{2}{*}{ Thailand } & $\begin{array}{l}\text { World Vegetable Center, } \\
\text { Kamphaeng Saen }\end{array}$ & 20 Nov. 2014 & S (5a) & $\mathrm{R}(0 \mathrm{c})$ & $\mathrm{R}(0 \mathrm{c})$ & $\mathrm{R}(0 \mathrm{~b})$ & $\mathrm{R}(0 \mathrm{~b})$ & $\mathrm{R}(0 \mathrm{c})$ & Mc-1 \\
\hline & $\begin{array}{l}\text { East-West Seed, Chiang } \\
\quad \text { Mai }\end{array}$ & 6 Sept. 2014 & S (5a) & $\mathrm{R}(0 \mathrm{c})$ & $\mathrm{R}(0 \mathrm{c})$ & $\mathrm{R}(0 \mathrm{~b})$ & $\mathrm{R}(0 \mathrm{~b})$ & $\mathrm{R}(0 \mathrm{c})$ & Mc-1 \\
\hline \multirow[t]{2}{*}{ Vietnam } & $\begin{array}{l}\text { Fruit and Vegetable } \\
\text { Research } \\
\text { Institute, Hanoi }\end{array}$ & 12 Sept. 2013 & $S(5 a)$ & $\mathrm{R}(0 \mathrm{c})$ & $\mathrm{R}(0 \mathrm{c})$ & $\mathrm{R}(0 \mathrm{~b})$ & $\mathrm{R}(0 \mathrm{~b})$ & $\mathrm{R}(0 \mathrm{c})$ & Mc-1 \\
\hline & $\begin{array}{l}\text { Southern Fruit Research } \\
\text { Institute, Ho Chi } \\
\text { Minh City }\end{array}$ & 12 Dec. 2013 & $S(5 a)$ & $\mathrm{R}(1 \mathrm{~b})$ & R (1a) & $\mathrm{R}(1 \mathrm{a})$ & $\mathrm{R}(1 \mathrm{a})$ & $\mathrm{R}(1 \mathrm{~b})$ & Mc-1 \\
\hline Philippines & East-West Seed, Bukidnon & 6 Sept. 2014 & $S(5 a)$ & $\mathrm{R}(0 \mathrm{c})$ & $\mathrm{R}(0 \mathrm{c})$ & $\mathrm{R}(0 \mathrm{~b})$ & $\mathrm{R}(0 \mathrm{~b})$ & $\mathrm{R}(0 \mathrm{c})$ & Mc-1 \\
\hline \multirow[t]{5}{*}{ India } & Rasi Seeds, Bangalore & 6 July 2013 & S (5a) & $\mathrm{R}(1 \mathrm{~b})$ & R (1a) & R (1a) & R (1a) & S (3a) & Mc-2 \\
\hline & Rasi Seeds, Pune & 7 Aug. 2013 & $S(5 a)$ & $\mathrm{R}(1 \mathrm{~b})$ & R (1a) & R (1a) & R (1a) & S (3a) & Mc-2 \\
\hline & VNR Seeds, Hyderabad & 8 Dec. 2013 & $S(5 a)$ & $\mathrm{R}(0 \mathrm{c})$ & $\mathrm{R}(0 \mathrm{c})$ & $\mathrm{R}(0 \mathrm{~b})$ & $\mathrm{R}(0 \mathrm{~b})$ & $\mathrm{R}(0 \mathrm{c})$ & Mc-1 \\
\hline & VNR Seeds, Raipur & 12 Aug. 2013 & $S(5 a)$ & S (3a) & $\mathrm{R}(0 \mathrm{c})$ & $\mathrm{R}(0 \mathrm{~b})$ & $\mathrm{R}(0 \mathrm{~b})$ & $S(3 a)$ & Mc-3 \\
\hline & VNR Seeds, Jagdalpur & 8 Dec. 2013 & $S(5 a)$ & $\mathrm{R}(0 \mathrm{c})$ & $\mathrm{R}(0.3 \mathrm{c})$ & $\mathrm{R}(0 \mathrm{~b})$ & $\mathrm{R}(0 \mathrm{~b})$ & $\mathrm{R}(0 \mathrm{c})$ & Mc-1 \\
\hline \multirow[t]{2}{*}{ China } & Enza Zaden, Qingyuan & 2 Apr. 2014 & $S(5 a)$ & $\mathrm{R}(0 \mathrm{c})$ & $\mathrm{S}(2.3 \mathrm{~b})$ & $\mathrm{R}(0 \mathrm{~b})$ & R (1a) & $\mathrm{R}(0 \mathrm{c})$ & Mc-4 \\
\hline & Clover Seeds, Kaiping City & 18 Mar. 2013 & $\mathrm{~S}(5 \mathrm{a})$ & $\mathrm{R}(0 \mathrm{c})$ & $\mathrm{R}(0 \mathrm{c})$ & $\mathrm{R}(0 \mathrm{~b})$ & $\mathrm{R}(0 \mathrm{~b})$ & $\mathrm{R}(0 \mathrm{c})$ & Mc-1 \\
\hline
\end{tabular}

${ }_{\mathrm{z}}$ Inoculated with spore suspensions 15 and $30 \mathrm{~d}$ after transplanting; evaluated for disease reaction $60 \mathrm{~d}$ after transplanting; summary disease rating $\mathrm{R}=$ resistant;

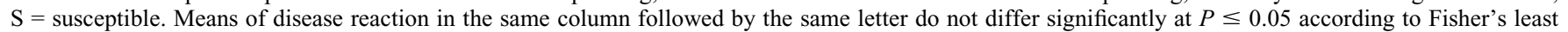
significant difference test.

symptoms; 1 = very light sporulation; $2=$ clear sporulation but not abundant; and $3=$ abundant sporulation. A plant rating of 0 was considered resistant and the others as susceptible.

Fruit trait evaluation. The five CPMresistant inbred lines were evaluated at Kamphaeng Saen, Thailand, for seven horticultural fruit traits: color, shape, skin pattern, fruit bitterness, fruit length, fruit width, and fruit weight (Table 3). The market class was designated as described in Dhillon et al., (2016). The experimental design was a randomized complete block design with three replications. Row spacing was $1.6 \mathrm{~m}$, withinrow spacing was $1.0 \mathrm{~m}$, with ten transplants per plot. Plants were trellised similar to the trial explained previously. Transplant date was 25 May 2014. Ten marketable fruit of each entry were harvested in each replication for assessment of fruit traits. Fruit bitterness was evaluated using fresh marketable fruit of each line, washed and cut into small $(\approx 3.0 \mathrm{~g})$ pieces, and assessed by a five-person taste panel. The evaluators rinsed their mouth with water after each sample. Two classes of bitterness were recorded: low and high.

Yield trials of two of the CPM-resistant breeding lines, THMC 143 and THMC 167 (along with CPM susceptible check THMC 144 and local cultivars), were performed at four locations: Kamphaeng Saen, Thailand; Nay Pyi Taw, Myanmar; Hanoi, Vietnam; and Dhaka, Bangladesh. The transplant dates at these four locations were 25 May 2014, 30 Aug. 2015, 11 Sept. 2015, and 10 Dec. 2014, respectively. The experimental design, row and plant spacing, and trellising were similar to the trial described previously. Plants were furrow irrigated, fertilized, and protected from pathogens and pests as per standard horticultural practices in each location. Fruit were harvested every $4 \mathrm{~d}$ for 7 weeks, for a total of 11 harvests per line at each location.

\section{Results}

Disease evaluation. The combined ANOVA revealed highly significant differences $(P \leq 0.01)$ among bitter gourd lines for mean disease rating (Data not shown). Location $\times$ line interaction was highly significant $(P \leq 0.01)$, indicating that bitter gourd lines performed differently among locations for reaction to CPM, thus indicating different $P x$ races among test locations. THMC 144 was susceptible to CPM at all 12 locations (mean rating $=5)($ Table 1$)$. In contrast, THMC 153 and THMC 167 were resistant to CPM at all 12 locations (mean rating $=0-1$ ). THMC 113 and THMC 143 were resistant at 11 locations (mean rating $=0-1)$ and were susceptible at one location in India and China, respectively. THMC 170 exhibited susceptible reactions at three (Bangalore, Pune, and Raipur) of the five locations in India and resistant reactions at nine locations in Thailand, Vietnam, Philippines, India, and China (with a mean rating = $0-1)$. The 12 CPM populations differed in pathogenicity based on the pattern of resistance reactions among the six bitter gourd lines, and four $P x$ races were tentatively identified (Table 1). All lines were resistant to race 1 . THMC 170 was susceptible to races 2 and 3. THMC 113 and THMC 143 were susceptible to races 3 and 4, respectively. Race 1 was observed in all five countries. Races 2 and 3 were observed only in India. Race 4 was only observed at one location in China.

All the bitter gourd lines, including the susceptible control, THMC 144, were resistant (no visible sporulation) in the growth chamber test to the six CPM strains isolated from cucurbits in Europe and the Mediterranean area that represented five races defined on melon CPM race differential lines (Table 2). The strain isolated from M. charantia from Thailand infected cucumber and summer squash, but not watermelon (Table 2). It was typed as melon race 1 based on reactions exhibited by the seven melon CPM race differentials, where 'Védrantais' and AR Hale's Best Jumbo were susceptible, and the other five were resistant with mean disease reactions $=0.0$.

Horticultural characterization and yield potential. The five CPM-resistant inbred lines produced spindle-shaped fruit with spiny skin surface (Table 3). Three fruit skin colors were observed in these lines: green (THMC 143), light green (THMC 113, THMC 153, and THMC 170), and dark green (THMC 167). The lines were categorized into two market segments based on the fruit length: short (THMC 113, THMC 153, and THMC 170) and medium (THMC 143 and THMC 167). Bitterness ratings of THMC 167 fruit were high, whereas those of the other four lines were low. Yields ( $t /$ ha) of THMC 143 and THMC 167 were comparable at each of the four locations (Table 4). Yields (t/ha) of CPM susceptible checks were significantly $(P \leq 0.05)$ less than these two CPMresistant lines in the trials conducted in Thailand, Myanmar, and Vietnam. BARI Koralla 1 is a popular CPM moderately resistant cultivar in Bangladesh, and its yield was comparable with the yields of THMC 143 and THMC 167.

\section{Discussion}

CPM caused by $P x$ is a major disease problem of cucurbit production worldwide (Kř́stková et al., 2009; Lebeda et al., 2016). CPM and begomoviruses are the chief bitter gourd production constraints encountered by the farmers in India (Dhillon et al., 2015; Khan et al., 2002). About $10 \%$ to $15 \%$ of the bitter gourd field cultivation cost in China and India is 
Table 2. Summary disease reactions of six bitter gourd-breeding lines to cucurbit powdery mildew (Podosphaera xanthii) in two growth chamber tests. One test included six CPM strains previously typed for pathogenic race on melon race differentials at Montfavet, France; the other test used a singlespore strain collected from bitter gourd in a field at Kamphaeng Saen, Thailand. Seven melon cucurbit powdery mildew race (CPM) differentials and one CPM pathotype differential of cucumber, watermelon, and squash were included to confirm race identities and to indicate pathotypes. Five plants of each test line were inoculated at the second leaf stage of growth.

\begin{tabular}{|c|c|c|c|c|c|c|c|}
\hline \multirow[b]{2}{*}{ Test line } & \multicolumn{6}{|c|}{ Melon strain } & \multirow{2}{*}{$\begin{array}{l}\text { Bitter } \\
\text { gourd } \\
\text { strain }\end{array}$} \\
\hline & $\begin{array}{l}\text { Sm-3 } \\
\text { (race 1) }\end{array}$ & $\begin{array}{c}\mathrm{S} 87-7 \\
\text { (race 2F) }\end{array}$ & $\begin{array}{l}00 \operatorname{Sm} 39 \\
\text { (race 3) }\end{array}$ & $\begin{array}{r}98 \mathrm{Sm} 65 \\
\text { (race 5) }\end{array}$ & $\begin{array}{c}04 \mathrm{Sm} 2 \\
\text { (race } 3.5 \text { ) }\end{array}$ & $\begin{array}{c}08 \mathrm{Sm} 9 \\
\text { (race 3.5) }\end{array}$ & \\
\hline \multicolumn{8}{|l|}{ Bitter gourd lines } \\
\hline THMC 144 & $\mathrm{R}^{\mathrm{Z}}$ & $\mathrm{R}$ & $\mathrm{R}$ & $\mathrm{R}$ & $\mathrm{R}$ & $\mathrm{R}$ & $\mathrm{S}$ \\
\hline THMC 113 & $\mathrm{R}$ & $\mathrm{R}$ & $\mathrm{R}$ & $\mathrm{R}$ & $\mathrm{R}$ & $\mathrm{R}$ & $\mathrm{R}$ \\
\hline THMC 143 & $\mathrm{R}$ & $\mathrm{R}$ & $\mathrm{R}$ & $\mathrm{R}$ & $\mathrm{R}$ & $\mathrm{R}$ & $\mathrm{R}$ \\
\hline THMC 153 & $\mathrm{R}$ & $\mathrm{R}$ & $\mathrm{R}$ & $\mathrm{R}$ & $\mathrm{R}$ & $\mathrm{R}$ & $\mathrm{R}$ \\
\hline THMC 167 & $\mathrm{R}$ & $\mathrm{R}$ & $\mathrm{R}$ & $\mathrm{R}$ & $\mathrm{R}$ & $\mathrm{R}$ & $\mathrm{R}$ \\
\hline THMC 170 & $\mathrm{R}$ & $\mathrm{R}$ & $\mathrm{R}$ & $\mathrm{R}$ & $\mathrm{R}$ & $\mathrm{R}$ & $\mathrm{R}$ \\
\hline \multicolumn{8}{|l|}{ Melon differentials } \\
\hline Védrantais & $\mathrm{S}$ & $\mathrm{S}$ & $\mathrm{S}$ & $\mathrm{S}$ & $\mathrm{S}$ & $\mathrm{S}$ & $\mathrm{S}$ \\
\hline PMR 45 & $\mathrm{R}$ & $\mathrm{S}$ & $\mathrm{S}$ & $\mathrm{S}$ & $\mathrm{S}$ & $\mathrm{S}$ & $\mathrm{R}$ \\
\hline PMR 5 & $\mathrm{R}$ & $\mathrm{R}$ & $\mathrm{S}$ & $\mathrm{R}$ & $\mathrm{S}$ & $\mathrm{S}$ & $\mathrm{R}$ \\
\hline WMR 29 & $\mathrm{R}$ & $\mathrm{R}$ & $\mathrm{R}$ & $\mathrm{S}$ & $\mathrm{S}$ & $\mathrm{S}$ & $\mathrm{R}$ \\
\hline PI 124112 & $\mathrm{R}$ & $\mathrm{R}$ & $\mathrm{R}$ & $\mathrm{R}$ & $\mathrm{R}$ & $\mathrm{R}$ & $\mathrm{R}$ \\
\hline 90625 (PI 313970) & $\mathrm{R}$ & $\mathrm{R}$ & $\mathrm{R}$ & $\mathrm{R}$ & $\mathrm{R}$ & $\mathrm{R}$ & $\mathrm{R}$ \\
\hline AR Hale's Best Jumbo & $\mathrm{R}$ & $\mathrm{R}$ & $\mathrm{S}$ & $\mathrm{S}$ & $\mathrm{R}$ & $\mathrm{S}$ & $\mathrm{S}$ \\
\hline $\begin{array}{l}\text { Cucumber differential } \\
\text { Marketer }\end{array}$ & $\mathrm{S}$ & $\mathrm{S}$ & $\mathrm{S}$ & $\mathrm{S}$ & $\mathrm{S}$ & $\mathrm{S}$ & $\mathrm{S}$ \\
\hline $\begin{array}{l}\text { Watermelon differential } \\
\text { Sugar baby }\end{array}$ & $\mathrm{R}$ & $\mathrm{R}$ & $\mathrm{R}$ & $\mathrm{R}$ & $\mathrm{R}$ & $\mathrm{R}$ & $\mathrm{R}$ \\
\hline $\begin{array}{l}\text { Summer squash } \\
\text { differential Diamant }\end{array}$ & $\mathrm{S}$ & $\mathrm{S}$ & $\mathrm{S}$ & $\mathrm{S}$ & $\mathrm{S}$ & $\mathrm{S}$ & $\mathrm{S}$ \\
\hline
\end{tabular}

${ }^{{ }^{\mathrm{R}}} \mathrm{R}$ resistant; $\mathrm{S}=$ susceptible.

Table 3. Fruit characteristics of five bitter gourd-breeding lines resistant to cucurbit powdery mildew incited by Podosphaera xanthii; Kamphaeng Saen, Thailand, 2014.

\begin{tabular}{lcccccc}
\hline & \multicolumn{5}{c}{ Breeding line } & LSD \\
\cline { 2 - 5 } Character & THMC 113 & THMC 143 & THMC 153 & THMC 167 & THMC 170 & $(P \leq 0.05)$ \\
\hline Fruit color & Light-green & Green & Light-green & Dark-green & Light-green & \\
Fruit shape & Spindle & Spindle & Spindle & Spindle & Spindle & \\
Skin pattern & Spiny & Spiny & Spiny & Spiny & Spiny & \\
Fruit length $(\mathrm{cm})$ & 4.3 & 16.9 & 5.7 & 16.7 & 5.1 & 0.9 \\
Fruit width $(\mathrm{cm})$ & 2.1 & 5.5 & 2.0 & 5.1 & 2.1 & 0.5 \\
Fruit weight $(\mathrm{g})$ & 8 & 144 & 8 & 129 & 45 & 36 \\
Fruit bitterness & Low & Low & Low & High & Low & \\
Market segment & Short & Medium & Short & Medium & Short & \\
Origin & Belize & India & Thailand & India & Taiwan & \\
\hline
\end{tabular}

${ }^{\mathrm{z}}$ Based on 10 marketable fruit of each entry from each of three replications.

Table 4. Fruit yield (tha $\mathrm{a}^{-1}$ ) of two powdery mildew-resistant bitter gourd lines and local checks evaluated in four locations across southeastern and south Asia.

\begin{tabular}{lcccc}
\hline & \multicolumn{4}{c}{ Location } \\
\cline { 2 - 5 } Line/cultivar & $\begin{array}{c}\text { Kamphaeng Saen } \\
\text { Thailand }\end{array}$ & $\begin{array}{c}\text { Nay Pyi Taw, } \\
\text { Myanmar }\end{array}$ & $\begin{array}{c}\text { Hanoi, } \\
\text { Vietnam }\end{array}$ & $\begin{array}{c}\text { Dhaka, } \\
\text { Bangladesh }\end{array}$ \\
\hline THMC 143 & 25.9 & 28.2 & 28.5 & 17.1 \\
THMC 167 & 21.8 & 19.1 & 24.3 & 18.9 \\
THMC 144 (Check) & 15.5 & - & - & - \\
MBG1504 (Check) & - & - & 7.7 & - \\
Dong Du (Check) & - & - & - & 22.3 \\
BARI Koralla 1 (Check) & - & 12.1 & 2.7 & 6.7 \\
LSD $(P \leq 0.05)$ & 4.4 & & &
\end{tabular}

attributed to the fungicides used to control CPM (J. Fu and V. Chawda, personal communication). Yield losses due to CPM infection are proportional to the severity of the disease and the length of the period that plants have been infected, and yield losses of up to $50 \%$ have been observed in bitter gourd number from two to 28 . However, the real number of races is much higher (Lebeda et al., 2016). Four races of $P x$ on watermelon have been reported in the United States (Davis et al., 2007; Kousik et al., 2011; Mercier et al., 2014; Zhang et al., 2011), and race $2 \mathrm{~W}$ has become more serious in recent years in the United States.

The differential reactions of the six lines used in these multilocation tests across Asia revealed four tentative $P x$ races on bitter gourd across the 12 locations (Table 1). Future research emphasis should be on evaluation of a wide array of bitter gourd germplasm for resistance to $P x$ isolates collected from bitter gourd fields in various parts of Asia to identify a set of bitter gourd differentials for identifying bitter gourd $P x$ races. We suggest $P x$ races identified on bitter gourd be given the prefix Mc- to distinguish them from races defined on other cucurbit species.

These results suggest that there are multiple races of $P x$ currently infecting $M$. charantia in southeast Asia and the Philippines. Pathotypes or forma specialis are defined by their differential pathogenicity among a set of host plant species and genera. The susceptible $M$. charantia control, THMC 144, was resistant to $P x$ strains isolated from other cucurbit species in Europe and the Mediterranean area; $M$. charantia could, therefore, be included in the differential set of host species to define pathotypes of CPM (Lebeda et al., 2008).

The sources of resistance to $P x$ in melon, watermelon, cucumber, and bottle gourd originated from the primary centers of diversity of these cucurbit species (reviewed in Dhillon et al., 2012; Kousik et al., 2008; Morishita et al., 2003; Tetteh et al., 2010). Two of the five resistant lines (THMC 143 and THMC 167) used in this study originated in India, the primary center of diversity of bitter gourd. THMC 144, which exhibited susceptible reactions to $P x$ isolates in all the locations across Asia, also originated in India. In a field evaluation conducted in 2016, THMC 143 and THMC 167 exhibited resistance to local $P x$ isolates in Myanmar and Bangladesh (N.P.S. Dhillon, unpublished data). THMC 153 and THMC 167 exhibited uniform resistance to local isolates of $P x$ in all the locations in the present study; it will be interesting to observe the reactions of these lines to $P x$ isolates from other parts of Asia. Elucidation of the $M$. charantia-Px interaction may be advanced by controlled inoculations (Lebeda and Sedláková, 2010) with well-defined bitter gourd races of $P x$ (Lebeda et al., 2016) originating from different Asian countries where $M$. charantia is grown. Such studies will also facilitate research on the genetic control of resistance in bitter gourd to CPM caused by $P x$.

Fruit traits of THMC 143 and THMC 167 (both belong to South Asian market segment) are appealing to the consumer: green or darkgreen fruit color, medium fruit length, and adequate fruit weight (129-144 g), whereas 
fruit of THMC 113, THMC 153, and THMC 170 are short and light-green with low mean weights $(8-45 \mathrm{~g})$ and are not preferred by consumers. Moreover, in multiple yield evaluation trials conducted in Thailand, Myanmar, Vietnam, and Bangladesh, THMC 143 exhibited good yield potential (Table 4). THMC 143 and THMC 167 are good candidates for use in South Asian-type bitter gourd-breeding programs for transferring the resistance through backcross breeding, as the desirable fruit color, shape, and weight of these lines will pose less of a challenge for genetic drag. THMC 143 exhibited good horticultural performance, including resistance to $P x$ in multiple trials conducted in Bangladesh, and has been released by Bangladesh Agricultural Research Institute for use in home gardens, and, in addition, it has been found resistant to other fungal diseases incited by Alternaria spp., Colletotrichum spp., and Cercospora spp., and it yields fruit over a longer period than varieties commonly grown at present in Bangladesh (M.A.T. Masud, unpublished data).

In conclusion, bitter gourd lines THMC 153 and THMC 167 were rated resistant to local isolates of $P x$ at 12 locations in five Asian countries. Four tentative $P x$ races of bitter gourd were also recorded during these multilocation evaluation trials. Lines THMC 143 and THMC 167, resistant to $P x$ at 11 and 12 locations, respectively, originated from India, possess desirable horticultural fruit traits and demonstrated good yield potential in field trials conducted at four locations in Asia, and would be potential sources of resistance for introgression of resistance into locally adapted bitter gourd cultivars. Genetic control of resistance in bitter gourd to CPM remains to be determined.

Note: Small seed samples of the lines used in this study are available on request, by using release codes, to: seedrequest@ worldveg.org. The release codes of THMC 113, THMC 143, THMC 144, THMC 153, THMC 167 and THMC 170 are AVBG1329, AVBG1330, AVBG1331, AVBG1333, AVBG1334 and AVBG1335, respectively.

\section{Literature Cited}

Abascal, K. and E. Yarnell. 2005. Using bitter melon to treat diabetes. J. Altern. Complement. Med. 1:179-184.

Block, C.C. and K.R. Reitsma. 2005. Powdery mildew resistance in the U.S. national plant germplasm system cucumber collection. HortScience 40:416-420.

Davis, A.R., A. Levi, A. Tetteh, T. Wehner, V. Russo, and M. Pitrat. 2007. Evaluation of watermelon and related species for resistance to race $1 \mathrm{~W}$ powdery mildew. J. Amer. Soc. Hort. Sci. 132:790-795

Dhillon, N.P.S., C.C. Lin, Z. Sun, P.M. Hanson, D.R. Ledesma, S.D. Habicht, and Y. Ray-Yu. 2017. Varietal and harvesting stage variation in the content of carotenoids, ascorbic acid and tocopherols in the fruit of bitter gourd (Momordica charantia L.). Plant Genet. Resources 15:248-259.

Dhillon, N.P.S., A.J. Monforte, M. Pitrat, S. Pandey, P.K. Singh, K.R. Reitsma, J. GarciaMas, A. Sharma, and J.D. McCreight. 2012. Melon landraces of India: Contributions and importance. Plant Breed. Rev. 35:85-150.

Dhillon, N.P.S., S. Phethin, C.C. Lin, W. Chen, J.F. Wang, C.S. Kousik, and J.D. McCreight. 2015. Preliminary evaluation of resistance to powdery mildew (Podosphaera xanthii) in AVRDC collections of bitter gourd, p. 25-27. In: J.D.A. Hughes, P. Kasemsap, S. Dasgupta, O.P. Dutta, S. Ketsa, S. Chaikiattiyos, G. Linwattana, S. Kosiyachinda, and V. Chantrasmi (eds.). Proc. Regional Symp. on Sustaining Small-scale Veg. Production Mktg. Systems for Food Nutr. Security (SEAVEG 2014). Publ. No. 15-785, AVRDC-The World Vegetable Center, Taiwan.

Dhillon, N.P.S., S. Sanguansil, R. Schafleitner, Y.W. Wang, and J.D. McCreight. 2016. Diversity among a wide Asian collection of bitter gourd landraces and their genetic relationships with commercial hybrid cultivars. J. Amer. Soc. Hort. Sci. 141:475-484.

Grover, J.K. and S.P. Yadav. 2004. Pharmacological actions and potential uses of Momordica charantia: A review. J. Ethnopharmacol. 93:123-132.

Keinath, A.P. and B. DuBose. 2004. Evaluation of fungicides for prevention and management of powdery mildew on watermelon. Crop Prot. 23:35-42.

Khan, J.A., M.K. Siddiqui, and B.P. Singh. 2002. The association of begomovirus with bitter melon in India. Plant Dis. 86:328.

Kousik, C.S., R.S. Donahoo, C.G. Webester, W.W Turechek, S.T. Adkins, and P.D. Roberts. 2011. Outbreak of cucurbit powdery mildew on watermelon fruit caused by Podosphaera xanthii in Southwest Florida. Plant Dis. 95:1586.

Kousik, C.S., A. Levi, K.S. Ling, and W.P. Wechter. 2008. Potential sources of resistance to cucurbit powdery mildew in U.S. plant introductions of bottle gourd. HortScience 43:1359-1364.

Křístková, E., A. Lebeda, and B. Sedláková. 2009. Species spectra, distribution and host range of cucurbit powdery mildews in the Czech Republic, and in some other European and middle eastern countries. Phytoparasitica 37:337-350.

Lans, C.A. 2006. Ethnomedicines used in Trinidad and Tobago for urinary problems and diabetes mellitus. J. Ethnobiol. Ethnomed. 2:45.

Lebeda, A. and E. Křístková. 1996. Genotypic variation in field resistance of Cucurbita pepo cultivars to powdery mildew (Erysiphe cichoracearum). Genet. Resources Crop Evol. 43:79-84.

Lebeda, A., E. Kř́stková, B. Sedláková, M.D. Coffey, and J.D. McCreight. 2011. Gaps and perspectives of pathotype and race determination in Golovinomyces cichoracearum and Podosphaera xanthii. Mycoscience 52:159-164.

Lebeda, A., E. Kř́stková, B. Sedláková, J.D. McCreight, and M.D. Coffey. 2008. New concept for determination and denomination of pathotypes and races of cucurbit powdery mildew, p. 125-134. In: M. Pitrat (ed.). Proc. Cucurbitaceae 2008. INRA, Avignon, France. Lebeda, A., E. Křístková, B. Sedláková, J.D. McCreight, and M.D. Coffey. 2016. Cucurbit powdery mildews: Methodology for objective determination and denomination of races. Eur. J. Plant Pathol. 144:399-410.

Lebeda, A., M.T. McGrath, and B. Sedláková. 2010. Fungicide resistance in cucurbit powdery mildew fungi, p. 221-246. In: O. Carisse (ed.). Fungicides. InTech, Rijeka, Croatia.

Lebeda, A. and B. Sedláková. 2010. Screening for resistance to cucurbit powdery mildews (Golovinomyces cichoracearum, Podosphaera xanthii), p. 295-307. In: M.M. Spencer and A. Lebeda (eds.). Mass screening techniques for selecting crops resistant to disease. Intl. Atomic Energy Agency (IAEA), Vienna.

McCreight, J.D., M.D. Coffey, B. Sedláková, and A. Lebeda. 2012. Cucurbit powdery mildew of melon incited by Podosphaera xanthii: Global and western U.S. perspectives, p. 181-189. In: N. Sari, I. Solmaz, and V. Aras (eds.). Proc. Cucurbitaceae 2012. Cukurova Univ., Antalya, Turkey.

McCreight, J.D., J.E. Staub, T.C. Wehner, and N.P.S. Dhillon. 2013. Gone global: Familiar and exotic cucurbits have asian origins. HortScience 48:1078-1089.

McGrath, M.T. 2006. Occurrence of fungicide resistance in Podosphaera xanthii and impact on controlling cucurbit powdery mildew in New York, p. 473-482. In: G.J. Holmes (ed.). Proc. Cucurbitaceae 2006. Universal Press, Raleigh, NC.

Mercier, J., M.J. Muscara, and A.R. Davis. 2014 First report of Podosphaera xanthii race $1 \mathrm{~W}$ causing powdery mildew of watermelon in California. Plant Dis. 98:158.

Morgan, W. and D. Midmore. 2002. Bitter melon in Australia. A report for the rural industries research and development corporation. Publ. No. 02/134:29.

Morishita, M., K. Sugiyama, T. Saito, and Y. Sakata. 2003. Powdery mildew resistance in cucumber. Jpn. Agr. Res. Qrtly. 37:7-14.

Tan, S.P., C.T.C. Kha, S.E. Parks, and P.D. Roach. 2016. Bitter melon (Momordica charantia L.) bioactive composition and health benefits: A review. Food Rev. Intl. 32:181-202.

Tetteh, A.Y., T.C. Wehner, and A.R. Davis. 2010. Identifying resistance to powdery mildew race $2 \mathrm{~W}$ in the USDA-ARS watermelon germplasm collection. Crop Sci. 50:933-939.

Thomas, C.E., A. Levi, and E. Caniglia. 2005 Evaluation of U.S. plant introductions of watermelon for resistance to powdery mildew. HortScience 40:154-156.

Wessel-Beaver, L. 1993. Powdery and downy mildew resistance in Cucurbita moschata accessions. Cucurbit Genet. Coop. Rpt. 16:73-74.

World Health Organization. 2016. World health day 2016: Beat diabetes. 23 Mar. 2017. <http://www. who.int/campaigns/world-health-day/2016/en/>.

Yuwai, K.E., K.S. Rao, C. Kaluwin, P.G. Jones, and D.E. Rivett. 1991. Chemical composition of Momordica charantia L. fruits. J. Agr. Food Chem. 39:1762-1763.

Zhang, H., S. Guo, G. Gong, Y. Ren, A.R. Davis, and Y. Xu. 2011. Sources of resistance to race $2 \mathrm{WF}$ powdery mildew in US watermelon plant introductions. HortScience 46:1349-1352. 